\begin{tabular}{|l|l|l||}
\hline \multicolumn{2}{|c|}{ PublisherInfo } \\
\hline \hline PublisherName & $:$ & BioMed Central \\
\hline \hline PublisherLocation & $:$ & London \\
\hline \hline PublisherImprintName & $:$ & BioMed Central \\
\hline \hline
\end{tabular}

\title{
Inhibitory effect of IL-10 on T cells by altering the CD28 signaling pathway
}

\begin{tabular}{|l|l|l||}
\hline \multicolumn{2}{|c||}{ ArticleInfo } \\
\hline \hline ArticleID & $:$ & 159 \\
\hline \hline ArticleDOI & $:$ & $10.1186 /$ ar-2000-66837 \\
\hline \hline ArticleCitationID & $:$ & 66837 \\
\hline \hline ArticleSequenceNumber & $:$ & 116 \\
\hline \hline ArticleCategory & $:$ & Paper Report \\
\hline \hline ArticleFirstPage & $:$ & 1 \\
\hline \hline ArticleLastPage & $:$ & 3 \\
\hline \hline & $:$ & RegistrationDate : 2000-9-8 \\
ArticleHistory & $:$ & OnlineDate \\
\hline \hline ArticleCopyright & $:$ & Current Science Ltd2000-8 \\
\hline \hline ArticleGrants & $:$ & \\
\hline \hline ArticleContext & $:$ & 130753311 \\
\hline \hline
\end{tabular}


Aff1 CNRS UPR 9021, Strasbourg, France

\section{Keywords}

CD4 T cells, CD28, regulatory T cells, Sjogrens syndrome

\section{Context}

IL-10 is a pleiotropic Th2 cytokine that inhibits Th1 cytokine production by T cells and induces T cell anergy in various mouse models. Recently, a $\mathrm{T}$ cell subset has been described, designated as $\mathrm{T}$ regulatory 1 cells, which produce high levels of IL-10 but little or no IL-2 and IL-4. These cells are able to inhibit antigen-specific $\mathrm{T}$ cell responses in both mice and human antigen presenting cell (APC)dependent culture systems. IL-10 diminishes the antigen presenting capacity of APCs by downregulating MHC class II expression. CD28 is an important costimulatory molecule for T cell proliferation and cytokine production. It has been shown that CD28-mediated signaling in murine $\mathrm{T}$ cell clones can block induction of anergy. However, little is known about the effect of IL-10 on T cells, particularly its involvement in the regulation CD28. To investigate the role of IL-10 in the induction of T cell unresponsiveness.

\section{Significant findings}

IL-10 inhibited anti-CD28 mediated-T cell proliferation but did not induce cell death. Although T cells stimulated with anti-CD28 mAb in the presence of IL-10 did not proliferate, they did show longterm survival. IL-10 induced unresponsiveness in T cells could also be reversed by certain stimuli such as IL-2 and anti-CD3, but not anti-CD28, indicating that these cells are probably anergic. The action of IL-10 was more precisely defined by the demonstration that IL-10 inhibited tyrosine phosphorylation of the CD28 molecule and the PI3-K p85 binding to CD28. Finally, production of various cytokines (both Th1 and Th2) was inhibited by IL-10, and neutralization of endogenous IL-10 in an antigen-specific stimulation by anti-IL-10 mAb enhanced both proliferation and cytokine production.

\section{Comments}


This paper describes the direct effect of interleukin (IL)-10 on T cells, and especially on its ability to alter the CD28 signaling pathway. This study provides new insights into the control of peripheral $\mathrm{T}$ cell responses, and particularly into the mechanism of anergy induction. The knowledge that IL-10 is increased in patients with systemic lupus erythematosus (Llorente et al, see Additional information) poses the question as to whether this cytokine is not able to induce anergy of autoreactive T cells. Previous studies have demonstrated that blockade of the B7/CD28 costimulation pathway induced longterm inhibition of murine lupus (Daikh et al, see Additional information). Thus, it would be interesting to examine if, in autoreactive T cells, IL-10 can reverse T cell unresponsiveness by altering the CD28 tyrosine phosphorylation and by blocking the binding of phosphatidylinositol 3-kinase (PI3-K) p85 to CD28.

\section{Methods}

Peripheral blood mononuclear cells (PBMC), monocyte-depleted PBMC and purified CD45RO+ T cells were stimulated with either plate-bound anti-CD28 or plate-bound anti-CD3 mAb and cultured in the presence of IL-10. Proliferation and cytokine secretion were determined by thymidine incorporation and ELISA, respectively. CD28 signaling events were determined by stimulation of PBMC in polystyrene tubes with anti-CD28 mAb in either the presence or the absence of IL-10. The reaction was stopped by adding lysis buffer, and the cell lysate was then immunoprecipitated with anti-CD28 mAb, immunoblotted and detected with an anti-PI3-K-p85 mAb.

\section{Additional information}

Llorente L, Richaud-Patin Y, Wijdenes J, Alcocer-Varela J, Maillot MC, Durand-Gasselin I, Fourrier BM, Galanaud P, Emilie D: Spontaneous production of interleukin-10 by B lymphocytes and monocytes in systemic lupus erythematosus. Eur Cytokine Netw 1993, 4:421-427 (PubMed abstract)

Daikh DI, Finck BK, Linsley PS, Hollenbaugh D, Wofsy D: Long-term inhibition of murine lupus by brief simultaneous blockade of the B7/CD28 and CD40/gp39 costimulation pathways. $J$ Immunol 1997, 159:3104-3108 (PubMed abstract)

\section{References}

1. Joss A, Akdis M, Faith A, Blaser K, Akdis CA.: IL-10 directly acts on T cells by specifically altering the CD28 co-stimulation pathway. Eur J Immunol. 2000, 30: 1683-1690.

This PDF file was created after publication. 